\title{
Differing Conceptions of Development and the Content of International Development Law
}

Daniel D. Bradlow

American University Washington College of Law, bradlow@wcl.amerian.edu

Follow this and additional works at: https://digitalcommons.wcl.american.edu/facsch_lawrev

Part of the Human Rights Law Commons, International Humanitarian Law Commons, and the International Law Commons

\section{Recommended Citation}

Bradlow, Daniel D., "Differing Conceptions of Development and the Content of International Development Law" (2005). Articles in Law Reviews \& Other Academic Journals. 935.

https://digitalcommons.wcl.american.edu/facsch_lawrev/935

This Article is brought to you for free and open access by the Scholarship \& Research at Digital Commons @ American University Washington College of Law. It has been accepted for inclusion in Articles in Law Reviews \& Other Academic Journals by an authorized administrator of Digital Commons @ American University Washington College of Law. For more information, please contact kclay@wcl.american.edu. 


\title{
DIFFERING CONCEPTIONS OF DEVELOPMENT AND THE CONTENT OF INTERNATIONAL DEVELOPMENT LAW
}

\author{
DANIEL D BRADLOW*
}

\begin{abstract}
International development law (IDL) is the branch of international law that deals with the rights and duties of states and other actors in the development process. Its original content was premised on a particular generally accepted understanding of development. Under the pressure of the problems of development that arose during the 1970s and 1980s this general agreement on the key issues disintegrated. As a consequence, the consensus on the content of international development law also began to break down. Today, competing idealised views of development shape the current debate about the content of international development law. What can be termed the traditional view' maintains that development is about economic growth. It argues that the challenges of economic development can be distinguished from other social, cultural, environmental and political issues in society, including human rights. What I call 'the modern view' has a holistic understanding of development. It argues that development should be viewed as an integrated process of change involving cconomic, social, cultural, political and environmental dimensions. The two perceptions differ in their understanding of the substantive content of IDL and the importance they attach to the principle of sovereignty and in their view of the relationship between national and international law in the law applicable to the development process.
\end{abstract}

\section{INTRODUCTION}

International development law (IDL) is the branch of international law that deals with the rights and duties of states and others involved in the development process. This suggests that the content of IDL depends on one's conception of development. Currently there is no general consensus on how the economic, social, political, cultural, spiritual and environmental aspects of human existence should be integrated into a coherent theory of development. Consequently, it is difficult to reach agreement on the content of IDL. This essay will demonstrate that one's understanding of the content of IDL depends to a large extent on one's view of the relationship between economic growth and the social (including human rights), environmental, political, and cultural aspects of the development process.

* Professor of Law and Director, International Legal Studies Program, American University, Washington College of Law, Washington, DC. The author thanks Maki Tanaka and Miki Kamijyo for their research assistance. 
This uncertainty suggests a useful structure for the paper. It will begin with a history of IDL. Thereafter it will discuss the two general categories in which different views of development can be classified and the different views of IDL that arise from each of these perceptions. The final section will consider likely future developments in our understanding of the content of IDL.

\section{A Brief History of International Development laW}

International development law began to emerge as a distinct body of law after the Second World War. It was inspired by the Latin American development theorists who argued that despite more than a century of political independence the development of Latin American countries was hampered by their dependent economic relations with Europe and North America. ${ }^{1}$ It gained further support in the era of decolonisation from the experience of the newly independent countries of Africa and Asia. These countries discovered that while they had won their political independence they did not have economic independence. They were locked into unequal and unfavourable economic relations with their former colonial masters that constrained their ability to develop. ${ }^{2}$ Examples of economic relationships that adversely affected the economic independence of developing countries were: (1) concession agreements that gave foreign investors long-term relatively unrestricted access to the resources of these countries at low $\operatorname{cost}^{3}$ and (2) unfavourable trade arrangements that gave the former colonial powers relatively easy access to their former colonies'

1 TC Lewellen Dependency and Development: An Introduction to the Third World (1995) 60 (in the 1940s, economists from United Nations's Economic Commission for Latin America first proposed dependency theory, which seeks to explain underdevelopment as being caused by unequal exchange in international capitalism).

$2 \mathrm{Eg}$, SKB Asante 'The Concept of Stability in Contractual Relations, in the Transnational Investment Process' in K Hossain (ed) Legal Aspects of the New International Economic Order (1980) 234, 244 (newly independent countries could not repudiate unfavourable agreements immediately upon political independence because of traditional doctrines such as pacta sunt servanda, sanctity of contract, acquired rights, and state succession).

$3 \mathrm{Eg}$, Aminoil v Kuwait (1982) 21 ILM 976, 1020-21 (unilateral termination of the oil concession despite the stability clause in the concession agreement); Saudi Arabia v Aramco (1958) 27 IL Rep 117, 118 (interpreting the scope of the company's rights granted by the concession agreement that stipulated exclusive concession for sixty years in the eastern part of Saudi Arabia'); N Schrijver Sovereignty Over National Resources: Balancing Rights and Duties (1997) 175 (discussing international concessions involving natural resources with examples of concession agreements between the British-owned Anglo-Persian Oil Company and Iran and between the Sheikh of Abu Dhabi and the Petroleum Development Company Ltd). Concession agreements are also used in mineral mining sectors. M Sornarajah The International Law' on Foreign Investment (1994) 31 (giving examples of mining agreements regarding gold fields in Ghana, which gave a concession for one hundred years, and similar concessions regarding ruby mines in Burma). 
market but denied comparable access to products, other than raw materials, from these countries. ${ }^{4}$

The international legal implications of these types of economic transaction were governed by the principles of international law, particularly those relating to state responsibility for the treatment of aliens and their property. These principles were primarily the creation of the countries of Europe and North America and were not particularly sensitive to the concerns of the developing countries in Africa, Asia and Latin America. Their primary focus in this regard was on protecting the sanctity of contractual arrangements and ensuring that foreign investors were treated according to certain minimum standards and that foreign owners of nationalised property were promptly, adequately and effectively compensated. ${ }^{5}$

The newly independent countries and sympathetic legal commentators realised that the international legal order, like the existing economic order, worked to their disadvantage. They began to fashion legal arguments to justify alterations in their economic relations and to gain greater control over their economic destinies. For example, they began to argue that the doctrine that all contracts should be fully honoured according to their terms - pacta sunt servanda - was not the only international legal principle applicable to international economic transactions. They proposed that its application should be modified by the well accepted public international law principle clausula rebus sic stantibus, which provides that changed circumstances can justify changing the terms of international agreements. ${ }^{6}$ This was particularly useful for those countries which found themselves locked into long-term unfavourable concession agreements. These sorts of arguments, which were based on existing international legal doctrine, fashioned the initial principles of IDL.

4 In the colonial era, charter companies, such as the Dutch East India and West Indies Companies and the British East India Company, gained advantageous trading and jurisdictional treatment through agreements with local rulers. Schrijver (note 3 above) 174. The former colonial powers continued to secure favourable trade relations after World War II by using tariff and non-tariff barriers to control imports from developing countries. A Mukerji 'Developing Countries and the WTO: Issues of Implementation' (2000) $34 \mathrm{~J}$ of World Trade 33, 36.

$5 \mathrm{Eg}$, Chorzow Factory Case (FRG v Pol) 1928 PCIJ ser A3 No 17, 47 (1928) (restitution to the foreign investor as remedy for nationalising state's breach of its contractual obligations); Asante (note 2 above) 237-39 (theoretical basis of stability of transnational investment agreements originates from traditional Anglo-American doctrines based on freedom of contract); FV Garcia-Amador The Emerging International Law of Development: A New Dimension of International Economic Law (1990) 126-29 (law and practice of compensation to foreign owners of nationalised property before World War II).

6 Asante (note 2 above) 242 (stating that the application of the doctrine of pacta sunt servanda to transnational investment agreements should be effectively limited under public international law by the doctrine of clausula rebus sic stantibus); Sornarajah (note 3 above) 348-49 (although foreign investors attempted to 'internationalise' transnational investment agreements so that the doctrine of pacta sunt sevanda would be applicable, they could not override other basic principles of international law). 
Thus, IDL began as an attempt to develop a more equitable legal approach to the core international economic issues of interest to developing countries, namely international trade relations and a state's responsibilities towards its foreign investors and their home state. Its initial objective was to develop legal principles and arguments that would help developing countries gain control over their economic destinies. IDL was successful in elaborating justifications for the unilateral modification of unfavourable economic agreements. It provided developing countries with a principled basis on which to terminate or renegotiate these agreements and to gain at least formal economic independence. These efforts received international legal recognition in such documents as the United Nations Declaration on Permanent Sovereignty over Natural Resources, ${ }^{7}$ the arbitral awards made in the cases arising from the nationalisation of the oil companies in the Middle East ${ }^{8}$ and in the negotiated compensation agreements that followed the nationalisation of key natural resources and other corporate enterprises in the developing countries. ${ }^{9}$

During this period the special needs of developing countries were recognised in other ways. For example, Part IV of the General Agreement on Tariffs and Trade (GATT), which allows developing countries to receive non-reciprocal trade benefits from their richer trading partners, was adopted in $1965 .{ }^{10}$ They also received some support for more generous capital flows. In 1960 the member states of the World Bank Group established the International Development Association to lend to the poorest developing countries on highly concessional terms. ${ }^{11}$ In the same year, the rich countries supported a UN General Assembly resolution imposing an obligation on them to provide financial assistance to developing countries. ${ }^{12}$

7 GA Res 1803, UN GAOR, 17th Sess, Supp No 17, at 15, UN Doc A.5217 (1962). GarciaAmador (note 5 above) 132-40 (evolution of the doctrine of permanent sovereignty from claims to the right to economic development and self-determination).

$8 \mathrm{Eg}$, Aminoil (note 2 above) 1023 (the stability clauses did not absolutely prohibit nationalisation; a state may nationalise foreign owned property provided it pays the requisite compensation); Aramco (note 3 above) 171-172 (the concession agreements under Saudi Arabian law and using public international law to fill the gaps in the Saudi Arabian law); Sornarajah (note 3 above) 339-40 (the host country's law is generally regarded as applicable to the concession agreements in oil concession arbitrations).

9 AA Akinsanya The Expropriation of Multinational Property in the Third World (1980) 78.

10 General Agreement on Tariffs and Trade, 30 Oct 1947, Protocol Amending the General Agreement to Introduce Part IV on Trade and Development and to Amend Annex I, 8 Feb 1965, 17 UST 1977, 572 UNTS 320 (Article 'VI that deals with non-reciprocal trade benefits to developing countries).

11 Articles of Agreement for International Development Association, 26 Jan 1960, 11 UST 2284, 439 UNTS 249 (entered into force 24 Sep 1960).

12 In 1960, the United Nations General Assembly formally adopted a target for financial flows to developing countries, pursuant to which developed countries were supposed to allocate one percent of their national income to international assistance including public loans and private investment. Accelerated Flow of Capital and Technical Assistance to the Developing 
These legal achievements, however, resulted in only limited economic success. By the 1970s, many developing countries still faced substantial barriers to development. Unfortunately, there was no longer any clear consensus about what these barriers were. As a result, there were also disagreements about the appropriate legal responses to them. Some saw the problems as being imbedded in the structure of the international economic order and called for a new international economic order (NIEO). ${ }^{13}$ Others, while not denying that there were problems with the international order, argued that the problems were primarily caused by the economic and political policy choices of the developing countries themselves and rejected these calls. ${ }^{14}$ During most of the 1970 s and early 1980s many IDL theorists and practitioners were focused on the debate about the need for a new international economic order and its implications for development and IDL.

The demands for an NIEO were eventually overwhelmed by the debt crisis of the 1980s. Thereafter the attention of the international community shifted to the internal barriers to and requirements for development in individual countries. Until recently relatively less attention was paid to the structure of the international order. This change in focus has generated an ongoing intense debate about the nature of the development process and the barriers to development. IDL has been and continues to be affected by this broader debate about development. The result is that today one's understanding of the content of IDL tends to depend on one's position in the broader debate.

Countries, GA Res 1522, UN GAOR 948th plen mtg 1 (1960). The Pearson Report, while adopting the principle that rich countries should provide a certain level of development assistance to poorer countries, proposed a reduced level of official development assistance (ODA). It recommended that donor countries offer at least 0,7 per cent of GNP preferably by 1979 and no later than 1980. LB Pearson et al Partners in Development (1970) 148-149 (hereinafter Pearson Report). See also note 44 below (discussing subsequent reaffirmation of this target and the unsatisfactory response of donor countries).

$13 \mathrm{Eg}$, Declaration on the Establishment of a New International Economic Order, GA Res 3201, UN Doc A/9559 (1974) (hereinafter UN Declaration on NIEO) (stating that states 'shall correct inequalities and redress existing injustices' and 'make it possible to eliminate the widening gap between the developed and developing countries'); Charter of Economic Rights and Duties of States, GA Res 3281, UN Doc A/9631 (1975) (hereinafter UN Economic Charter) (calling for the establishment of a new international economic order designed to remove major hurdles to economic development in developed countries); Resolution on an International Development Strategy for the Third UN Development Decade GA Res 35/56, UN Doc A35/56 (1981) (hereinafter International Development Strategy) (recognising imbalances and inequities between developed and developing countries in the present system of international economic relations and seeking to restructure the existing international economic order). See also Kamal Hossain (ed) Legal Aspects of the New International Economic Order (1980) 1, 2.

14 Eg,World Bank, Sub-Saharan Africa: From Crisis to Sustainable Growth 23-30 (citing various factors including 'deteriorating governance' as factors behind the African economic decline); $\mathbf{R}$ Gulhati The Political Economy of Reform in Sub-Saharan Africa: Report of the Workshops on the Political Economy of Structural Adjustment and the Sustainability of Reform (1989) 3-4 ('policy and institutional distortions' as a crucial factor of the African economic crisis). 
Most positions in the debate can be classified as one of two competing idealised views of development. It is to these two views and their legal implications that I now turn.

\section{Competing Views of Development}

There was a time when there was a general consensus that development was about economic growth ${ }^{15}$ and that, at least analytically, it could be treated as a separate problem from other social, cultural and political issues in society. Today, however, that consensus has broken down. Now many people argue that development must be seen holistically, as an integrated process of change that involves economic, social, cultural, political and environmental dimensions. ${ }^{16}$ The debate between these two positions has not been resolved and today the various competing views can be categorised as two contending approaches to development that can be termed 'the traditional view' and the 'modern view'. Each of these idealised views leads to a different understanding of the content of IDL.

A few key issues divide these views. These include the role that the state should play in development, whether development is purely an economic process or whether it should be viewed more holistically so that issues such as human rights are seen as an integral part of the development process. The other concerns the relationship between international and national regulation. ${ }^{17}$ More precisely, they differ over whether the state

15 In conventional neoclassical models, human welfare is measured by increases in consumption of goods and services. J Weaver \& K Jameson Economic Development: Competing Paradigms (1981) 10-11. Accordingly, the conventional development economics literature focuses on removing barriers to economic growth. PR Agénor \& PJ Montiel Development Macroeconomics (1996) 3. This was reflected in the international discourse about development. In 1961 the United Nations General Assembly adopted an economic growth rate of five per cent in national income as a target for developing countries. Resolution on United Nations Development Decade: A Programme for International Economic Co-operation (I), UN Res 1710, UN GAOR, 2d Comm 16th Sess, 1084th plen mtg (1961) 1. The Pearson Report proposed as a target an annual growth rate of GNP 6 per cent. Pearson Report (note 12 above) 28.

16 Declaration on the Right to Development, GA Res 41/128, UN Doc A/41/128 (1987) (dealing with development as a 'comprehensive economic, social, cultural and political process'); World Bank Comprehensive Development Framework (balanced approach to development policymaking by considering interdependence of economic and non-economic factors) <http:// www.worldbank.org/cdf/> ; World Bank World Development Report 2000/200I: Attacking Poverty (2000) (multi-dimensional indicators of well-being, such as education, health, and security, as well as levels of income and consumption and arguing that it is possible to reduce all dimensions of poverty). United Nations Development Programme Human Development Report (2000) 139-268.

17 Many observers would consider that another key issue for developing countries is the existing arrangements for the governance of the international economic order. Since this issue relates primarily to the structure and functions of the international economic organisations, it can be viewed more as a problem of international organisations than of IDL. Therefore, it is treated as outside the scope of this essay. For more information, see, eg, DD Bradlow 'The World Bank, the IMF and Human Rights' (1996) 6 Transnational L\& Contemporary Problems 47; DD Bradlow 'Should the International Financial Institutions Play a Role in the Implementation and Enforcement of International Humanitarian Law?' (2002) 50 Univ of 
should have the primary role in decision-making relating to development policy and projects. They also differ about the scope and nature of the responsibilities of the various participants in the planning, construction and operation of development projects and in the design and implementation of development policy. This means that a key area of disagreement is the definition of the appropriate legal and other relationships between the following four groups involved in development policy-making and projects: the state, which approves development projects and makes and implements development policy; project sponsors, who may be the private sector, the public sector or the state itself; project contractors, including those public and private sector institutions which provide the financing, goods and services for the design, construction and operation of development projects and for the implementation of development policies; and individuals and communities directly or indirectly affected, in both positive and negative ways, by particular policies and projects and their representatives.

The two views of development, the relationships they posit between these different groups and the implications of each of these views for IDL are discussed below. As will be seen one's conception of development influences one's understanding of the content of IDL in four ways. First, it shapes one's view of the substantive content of IDL. Second, it helps define one's perception of the relationship between the sovereign and the other actors in the development process. Third, it influences the degree to which one understands IDL as 'international' as opposed to 'transnational' law. Fourth, it determines one's idea of the role that international human rights law plays in IDL.

\section{(a) The Traditional View}

The traditional view is advocated by elements of the business community, governments, and international organisations.

Those who espouse this view see development primarily as an economic process that consists of discrete projects (for example: building a dam, a road, a school, a factory, a mine or a telecommunications system) and specific economic policies. It recognises that development has social, environmental, and political implications but argues that these can be dealt with separately from the economic aspects.

The proponents of this view divide decision-making about these projects and policies into two parts. First, there are broad policy issues about which decisions are made through the political process by the

Kansas LR 695; DD Bradlow 'Stuffing New Wine Into Old Bottles: The Troubling Case of the IMF' (2001) $3 J$ of Int Banking Reg 9; DD Bradlow 'The Times They Are A-Changin': Some Preliminary Thoughts on Developing Countries, NGOs and the Reform of the WTO' (2001) 33 George Washington Int LR 503; C Grossman \& DD Bradlow 'Are We Being Propelled Towards a People-Centered Transnational Legal Order?' (1993) 9 American Univ J of Int L \& Policy 1. 
government and society in which the policy or project will be implemented. Examples of broad policy issues include: (1) whether the budget should allocate additional resources to health and education or to energy and national defence; (2) whether to build a system of highways or public transport; and (3) whether to promote export oriented or locally focused industries.

The second category involves specific project or policy decisions. Examples include: (1) how should a dam be constructed, or (2) what exactly should be done to promote local industries.

According to this view, the first responsibility of the project sponsors and contractors is to evaluate each project in terms of its technical, financial and economic feasibility. As long as all technical problems can be resolved, the economic and financial benefits exceed the costs and it is expected to produce the desired rate of return, a project is justified and is treated as developmentally beneficial. ${ }^{18}$ The remaining duty of the project sponsors and contractors is to execute their contractual obligations faithfully and efficiently.

The traditional view allows the project sponsors and contractors to treat all other issues, that is broad policy issues, including social and environmental issues, as externalities. These issues are perceived as the prerogative of the society or government for which the project is being built. $^{19}$ This means that the sponsors' and contractors' operating assumption is that the government concerned or the society in which the project is located will decide how it wishes to manage its own environment and to share the costs and benefits of the project among the various stakeholders. The contractors and sponsors can treat these decisions as background facts during negotiations and as fixed variables in their own planning.

To the extent that the various project stakeholders, other than the sponsors and contractors, wish to be involved in the project's decisionmaking process, they will need to consult with the government because it has control over the broad social, political, environmental, and cultural implications of the project. These other stakeholders will only need to consult with the sponsors or contractors on specific technical issues related to the design, construction or operation of the project.

18 WC Baum \& SM Tolbert Investing in Development: Lessons of World Bank Experience (1985) 418-68 (cost-benefit analysis, cost recovery, and financial performance in project analysis).

19 This view is reflected in a number of official documents, eg, Articles of Agreement of the International Bank for Reconstruction and Development, 22 July 1944, art IV, 10, 60 Stat 1440 (hereinafter World Bank Articles of Agreement) ("The Bank and its officers shall not interfere in the political affairs of any member; nor shall they be influenced in their decisions by the political character of the member or members concerned.'); Organisation for Economic Development (OECD), The OECD Guidelines for Multinational Enterprises art II (27 June 2000), <http://www.oecd.org/dataoecd/56/36/1922428.pdf> (advising multinational enterprises to (a)bstain from any improper involvement in local political activities'). 
For two reasons, decision-making in these circumstances is likely to be 'top-down'. First, most project contractors are private companies whose managers have been hired by the owners to run the companies for their benefit. This means that they are expected to make all project-related decisions with this objective in mind. ${ }^{20}$ Public sector project sponsors and contractors similarly have to account to their owner - the state (or states in the case of multilateral institutions) - for how they use their assets. This suggests that they are also likely to have a top-down decisionmaking structure.

Second, while the managers may feel the need to consult with others before making any particular project decision, the range of people with whom they must consult is limited. Since the sponsors and contractors are only responsible for technical and financial issues, their senior management needs only to consult with experts on these issues before making their decisions. To the extent that the project requires a broader consultative process, this would only relate to the social and environmental externalities that are the responsibility of the government and not the sponsors or contractors.

The traditional view makes it easy to identify to whom the different participants in the project are accountable. Project sponsors and contractors are only accountable to three groups: government regulators for their compliance with the applicable regulations; those who hired them for the performance of their contractual obligations and their owners or shareholders for their management of the enterprise.

The sponsors and contractors will only be accountable to the project's intended beneficiaries and to those adversely affected by the project in two situations. The first is when they have a direct contractual relationship with these other stakeholders and have failed to perform their contractual obligations. The second is when they have committed a tort against these other stakeholders and there is a forum that is willing to entertain the victims' claim. This forum could either be a national court or an international body.

The state, as the party with decision-making responsibility for the broader social and environmental aspects of the project, is accountable to the beneficiaries and those harmed by the project. Accountability is imposed on the state through the political system. In other words, the proponents of the traditional view are relying on the two primary mechanisms of accountability in democratic governance to hold governments responsible for their decisions and actions relating to

20 Shareholders maintain control over the board of directors through shareholder election or removal of directors and shareholder resolutions and approvals. HG Henn \& JR Alexander Law's of Corporations 3 ed (1983) 511-17. Moreover, the board of directors has various duties, primarily to the corporation, and a fiduciary duty to shareholders. Ibid 611-61. 
specific policies or projects. The first of these mechanisms is the periodic holding of elections for a new government. Thus, interested persons can hold the government, which has sponsored or approved the project, accountable for its actions by voting against it in the next election. This is not a particularly effective means of accountability for specific projectrelated decisions. It is unlikely that the electorate as a whole will base its decision on the government's conduct over one project that may only affect a portion, possibly a very small portion, of the electorate. The second is whatever administrative or judicial procedures the state may have established through which interested private actors can challenge governmental decisions.

It should be noted that the top-down nature of decision-making and the limited accountability described above both suggest that the traditional view contemplates a very limited role for non-governmental organisations (NGOs) in development. Unless these groups can act as project sponsors or contractors their role is limited to assisting project victims hold project decision-makers accountable for their decisions and actions in the project. Their efficacy in doing so will depend, in the first instance, on how much access they have to judicial and administrative tribunals and to the media. They may also be able to hold decisionmakers accountable through international forums and through developing international campaigns in conjunction with international NGOs. ${ }^{21}$

The third implication of the traditional view is that it places some constraints on the topics that are open for negotiation in any development transaction. Since broad social, political and environmental decisions are the prerogative of the state, they are outside the scope of the negotiations between the project sponsors and the government or the project sponsors and the project contractors. In both sets of negotiations, the broad social, environmental and political parameters of the project are treated as fixed and the parties must negotiate the terms of their transaction within these parameters. This is consistent with the legal rule that the obligation of a foreign sponsor or contractor is to obey the law of the host state and to refrain from interfering in its affairs. ${ }^{22}$

A fourth implication is that the traditional view of development is consistent with traditional notions of sovereignty. By treating social, political and environmental factors as project externalities proponents of the traditional view are implicitly defining the scope of the state's sovereignty with regard to the other actors in development. It is making clear that decisions relating to the social, political and environmental consequences of development should be taken by the sovereign and its decisions should be respected by the other players.

21 See notes 68-70 below and the accompanying text (discussing these international forums and the growing ability of stakeholders to internationalise their concerns).

22 Sornarajah (note 3 above) 15l-162 (the territoriality principle provides the basis for the host state's jurisdiction over foreign investors). 


\section{(b) The traditional view of development and IDL}

\section{(i) The substantive content of $I D L$}

The traditional view of IDL focuses on economic law issues and, specifically, international economic law issues. More specifically, the traditional view of development conceives of IDL as being a specialised branch of international economic law - the branch that deals with those international legal aspects of international trade, finance and investment that relate to the challenges facing developing countries. $^{23}$

This means that in the trade area IDL focuses on those aspects of international trade law that are of most interest to developing countries. These would include, for example, issues relating to special and differential treatment for developing countries through such programmes as the Generalised System of Preferences (GSP); ${ }^{24}$ and the impact of the Trade Related Aspects of Intellectual Property Rights (TRIPS Agreements) on developing countries. ${ }^{25}$ In addition, IDL would include efforts to make trade in commodities more predictable ${ }^{26}$ and to develop legal arguments that support changes designed to make the international trading system more equitable. ${ }^{27}$ Similarly, in the investment area, traditional IDL focuses on such issues as nationalisation and compensa-

23 FV Garcia-Amador (note 5 above) 35-36 (two basic elements of IDL are the states' duties and responsibilities to co-operate for development and rights to development including preferential treatment in trade and development assistance); AH Qureshi, International Economic Law' (1999) 338 (noting that IDL deals with an area of international economic law that can be a matter of controversy between developing and developed countries).

24 The UNCTAD originally laid out the principles of the GSP. Preferential or Free Entry of Exports of Manufactures and Semimanufactures of Developing Countries to the Developed Countries, UNCTAD, UN Doc. TD/97/Annexes (1968). EJ de Hann 'Integrating Environmental Concerns into Trade Relations' in International Economic Law with a Human Face (1998) 307, 309-310 (characteristics of the UNCTAD General System of Preferences). The principle gained a legal basis in the GATT as the 'Enabling Clause' agreed in the Tokyo Round in 1979 in accordance with Part IV. Differential and More Favourable Treatment: Reciprocity and Fuller Participation of Developing Countries, 28 November 1979, L/4903. GATT BISD (26th Supp) (1980) 203; Hann ibid 311.

25 Agreement on Trade-Related Aspects of Intellectual Property Rights, 15 April 1994, Marrakesh Agreement Establishing the World Trade Organisation, Annex 1C, Legal Instruments - Results of the Uruguay Round vol 31 (1994) 33 ILM 81.

26 UN Economic Charter (note 13 above) art 6 ("All States share the responsibility to promote the regular flow and access of all commercial goods traded at stable remunerative and equitable prices ...); Qureshi (note 23 above) 337 (referring to commodity agreements as providing a cooperative or facilitative framework for development).

27 Eg, M Bulajić Principles of International Development Law: Progressive Development of the Principles of International Law Relating to the New International Economic Order 2 ed (1993) 287-98 (discussing the principle of preferential and non-reciprocal treatment for developing countries as a tool to change substantive inequity between developed and developing countries). 
tion, ${ }^{28}$ the treatment and responsibilities of investors ${ }^{29}$ and host state regulation of and incentives for investors. ${ }^{30}$ It also deals with questions of political risk and the resolution of disputes between investors and their host countries. ${ }^{31}$ Finally, in the international financial area, IDL has focused on such issues as access to capital, ${ }^{32}$ debt renegotiation, ${ }^{33}$ the operations of the Bretton Woods Institutions, ${ }^{34}$ and foreign aid. ${ }^{35}$

While there may be general agreement among all proponents of the traditional view of development about the types of issues addressed by IDL, there is no agreement about the doctrines that form its content. Originally, the debates about these doctrines reflected the differing perceptions of international economic transactions held by capital exporting and capital importing countries. Today, while the lines of disagreement still largely coincide with these two general categories, it is more accurate to state that the divisions reflect the different perceptions

28 Garcia-Amador (note 5 above) 126-31 (explaining principles concerning nationalisation and compensation in traditional international law); Sornarajah (note 3 above) 253-260 (describing the controversies over the standard formulation of compensation for nationalised foreign owned property).

29 Bulajić (note 27 above) 170 (outlining international efforts to create principles regarding the regulation and treatment of transnational economic relations); Garcia-Amador (note 5 above) 159-71 (dealing with the treatment of foreign investment and the law governing state contracts with foreign investors); Sornarajah (note 3 above) 121-33 (discussing controversies in host states' responsibility for injuries to foreign investors).

30 Sornarajah (note 3 above) 83-143 (examining host states' control over foreign investment, including regulation of entry and other public policy requirements); Qureshi (note 23 above) 337 (regarding the regulation and protection of foreign investment as elements in the traditional normative framework of development); JW Salacuse 'From Developing Countries to Emerging Markets: A Changing Role for Law in the Third World' 33 Int Law 875, 879, 88586 (discussing dominant development models and noting that until 1980s focus was on the regulation of foreign investment but that since then it has been on the promotion of foreign investment).

31 Bulajić (note 27 above) 230 (identifying 'peaceful settlement of economic disputes' as one of the traditional principles incorporated in IDL); Garcia-Amador (note 5 above) 174-187 (examining law concerning settlement of disputes between foreign investors and states in relation to developing countries' claim of permanent sovereignty); Sornarajah (note 3 above) 55-65, 375-99 (political and other risks involved in foreign investment and the resolution of investment disputes through international tribunals and national courts). For the role of the World Bank Group in international investment disputes, see IFI Shihata 'The Settlement of Disputes Regarding Foreign Investments: The Role of World Bank Group' in F Tschofen \& AR Parra (eds) The World Bank in a Changing World (1991) 287-308; IFI Shihata 'Towards a Greater, Depoliticization of Investment Disputes: The Roles of ICSID and MIGA' in F Tschofen \& AR Parra (eds) The World Bank in a Changing World (1991) 309-42.

$32 \mathrm{Eg}$, Bulajic (note 27 above) 168 (detailing attempts to create the Multilateral Investment Guarantee Agency (MIGA) to stimulate capital flow particularly to developing countries); Shihata, (note 31 above) 271-86 (providing details on the function of the MIGA).

33 Bulajic (note 27 above) 14-20 (considering the indebtedness of developing countries to be the responsibility not only of those countries but also of international financial institutions and the lender countries).

34 Qureshi (note 23 above) 337 (mechanisms to encourage developing countries to participate in international economic organisations).

35 Ibid (development assistance in the co-operative or facilitative framework for development); Garcia-Amador (note 5 above) 83- 95 (discussing developing countries' claim to development assistance based on the right to development). 
of the proponents and opponents of the NIEO that was proposed by developing countries in the 1970s.

The NIEO included an attempt by developing countries to develop a new legal framework for the global economy that was more equitable than the existing framework. ${ }^{36}$ It had a number of objectives. First, it sought to ensure that each state could control economic activity within its own borders. For example, the NIEO would have required foreign entities to respect national sovereignty over natural resources. It also obliged states to provide national treatment to foreign investors.

Second, it sought to ensure that economic relations between states were designed to provide developing countries with more stable incomes for their primary commodity exports and greater assured access to technology and international finance and investment. In order to achieve these objectives, the proponents of the NIEO called for the UN to adopt Codes of Conduct on Transnational Corporations, ${ }^{37}$ Restrictive Business Practices ${ }^{38}$ and

36 Developing countries had articulated grievances with the prevailing economic order and attempted to shape a new economic order since the 1950s. K Hossain, 'Introduction: General Principles, the Character of Economic Rights and Duties of States and the NIEO' in K Hossain (ed) Legal Aspects of the New International Economic Order (1980) 1, 2. The developing world perceived disadvantages generally in international economic relations and particularly in international trade. Ibid. The first attempt to introduce a new economic order was made in 1952, when Chile raised the issue in terms of permanent sovereignty over natural resources in discussions relating to the Draft International Covenant on Human Rights. $M$ Bulajić 'Legal Aspects of New International Order' in K Hossain (ed) Legal Aspects of the New' International Economic Order (1980) 45, 46. Developing countries formally called for 'a new international economic order' at the Non-Aligned Summit in 1973. See Hossain (note 13 above) 1 .

37 In 1976, the UN Commission on Transnational Corporations created an Intergovernmental Working Group. In its final report in 1982 this group proposed a draft text for the Code of Conduct on Transnational Corporations. See Bulajić (note 27 above) 169-70. UN Commission on Transnational Corporation, Draft United Nations Code of Conduct on Transnational Corporations (1984) 23 ILM 626 (hereinafter 'Draft Code on Transnational Corporations'). Despite the Commission's subsequent attempts to finalise the draft, some controversial issues remained unresolved. UN Commission on Transnational Corporation, Report of the Secretariat: Compilation of the Formulation of the United Nations Code of Conduct on Transnational Corporations, 198423 ILM 602 (hereinafter UNCTC Report) (outstanding issues of the Draft Code on Transnational Corporations); Bulajic (note 27 above) 170-74 (examining attempts by coalitions of developing countries to create United Nations Code of Conduct on Transnational Corporations and the problems that frustrated their attempts); $\mathrm{E}$ Kelly, "National Treatment" and the formulation of a Code of Conduct for Transnational Corporations' in Hossain (Note 36 above) Legal Aspects of the New International Economic Order (1980) 137, 153-155 (developing countries' demands concerning national treatment in the Draft Code of Conduct on Transnational Corporations).

38 In 1968, the UNCTAD II decided to initiate research on restrictive business practices. This research was reduced to a set of principles and rules in subsequent sessions of an ad hoc working group within the UNCTAD. Bulajić (note 27 above) 55 . In 1980 parties agreed to a set of principles and rules to govern restrictive business conduct. The Set of Principles and Rules on Restrictive Business Practices, GA Res 35/63, UN Doc A/Res/35/63 (1980). Bulajić (note 27 above) 55-57. 
Transfer of Technology. ${ }^{39}$ These codes were intended to regulate the rights and responsibilities of the state and foreign entities in international transactions in such a way as to ensure that these transactions did not perpetuate the unequal economic relations that characterised the colonial era.

Third, the NIEO sought to enhance the role of developing countries in the governance of the international economy by promoting the United Nations (UN) as the forum for discussion of issues of interest to developing countries. The UN was seen as preferable to the Bretton Woods institutions (the World Bank and the International Monetary Fund) because in the United Nations General Assembly each country has an equal vote. The Bretton Woods institutions, on the other hand, use a weighted voting system which favours the richer countries. ${ }^{40}$

The proponents of the NIEO persuaded the General Assembly to adopt The Charter on the Economic Rights and Duties of States ${ }^{41}$ and to create a Center on Transnational Corporations. ${ }^{42}$ They also pushed for the United Nations to develop and adopt the Codes of Conduct referred to above. ${ }^{43}$ While the issues covered by these documents are complex and a detailed analysis of their content is beyond the scope of this paper, they all share an interest in enhancing the bargaining power of developing countries in relation to multinational corporations and their home country governments and giving them more control over their own economic futures.

39 The first session of the UN Conference on an International Code of Conduct on the Transfer of Technology was held in 1978 and the substantive part of the code was created in the first three sessions of the Conference. Bulajic (note 27 above) 174-75. However, the subsequent sessions of the Conference were unsuccessful in establishing the International Code of Conduct for the Transfer of Technology as an essential component of the NIEO. Bulajic (note 27 above) 175-77. Draft International Code of Conduct for the Transfer of Technology, UN Conference on Trade and Development, UN DOC TD/TOT/47, 1 (1985).

40 World Bank Articles of Agreement (note 19 above) art V § 3; Articles of Agreement of International Monetary Fund, 22 July 1944, art XII 3, 60 Stat 1401. UN Institute for Training and Research, International Financial Institutions, Module 5, 12-13, 31 (the weighted allocation of voting power in the IMF and in the World Bank that takes account of differences in member states' contributions and shares). See also Bradlow 'Stuffing New Wine' (note 17 above); A Burria 'The Governance of the IMF in a Global Economy' in A Burria (ed) Challenges to the World Bank and the IMF: Developing Country Perspectives (2003) (both articles discuss the problems with and reform of the weighted voting system in the IMF).

41 UN Economic Charter (note 13 above). Bulajić (note 27 above) 111 (examining proposals, negotiations, and adoption of the Charter of Economic Rights and Duties of States).

42 The United Nations Center on Transnational Corporations was created in 1974 by a resolution adopted in the ECOSOC. ESC Res 1903, UN ESCOR, UN Doc E/5570 (1974). It has subsequently been reduced to a programme on foreign direct investment in the division on investment, technology and enterprise development of UNCTAD.

43 See notes 37-39 above and accompanying text (dealing with efforts to establish United Nations Code of Conduct on Transnational Corporations and attempts to draft the Set of Principles and Rules on Restrictive Business Practices and International Code of Conduct for the Transfer of Technology). 
The proponents of the NIEO also attempted to impose new obligations on capital exporting countries. These obligations, while not necessarily legally enforceable, were intended to encourage the rich countries to act in solidarity with the countries of the south and to respect the sovereignty of developing countries. For example, the industrialised countries were encouraged to accept an obligation to commit 0,7 per cent of their national income to financial aid for developing countries. ${ }^{44}$ Pursuant to Part IV of the GATT, the rich northern countries agreed to grant developing countries non-reciprocal trade benefits that were more generous than those offered to other GATT contracting parties. ${ }^{45}$ This commitment resulted in the Generalized System of Preferences under which many rich countries allow duty free access or impose lower tariffs, on specific products from qualifying developing countries than they offer to other GATT contracting parties. ${ }^{46}$ This commitment has been carried over into the World Trade Organisation, the successor to the GATT.

The legal advocates of the NIEO also sought to expand the ability of developing countries to control economic activity in their own territory. For example, they argued that the treatment of foreign investors should be governed by the Calvo Clause, according to which all foreign investors must respect and are subject to the laws and exclusive jurisdiction of their

44 The 0,7 per cent target proposed by the Pearson Report has been reaffirmed in subsequent international discourses on development, eg, International Monetary Fund (IMF) 'Group of Twenty-Four Report on Changes in the Monetary System' (1985) 24 ILM 1699, 1714 (developed countries agreed to spend 0,7 per cent of GNP for ODA at United Nations Conference on Trade and Development VI in 1984). Note 12 above (discussing the 0,7 per cent target in the Pearson Report). Developing countries have demanded that developed countries fulfil their internationally agreed obligation. Ibid (urging developed countries to accelerate their efforts to reach the target). Moreover, the target was reaffirmed in the United Nations Conference on Efivironment and Development (UNCED). Agenda 21, UN Doc A/ CONF.151/4 (1992) ('Developed countries reaffirm their commitments to reach the accepted United Nations target of 0.7 per cent of the GNP for ODA and, to the extent that they have not yet achieved that target, agree to augment their aid programmes in order to reach that target as soon as possible ...'). See also Statement of Johannesburg Summit on Rio plus 10 (2002) <http://www.un.org/esa/sustdev/index.html > and Monterrey Consensus <http:// www.un.org/esa/ffd/aconf198-3.pdf > (statements reaffirming this commitment). However, as of 2002, the average actual ODA contributions of the member states of the OECD Development Assistance Committee was 0,4 per cent. World Bank Global Development Finance 2004, Vol. 1, Analysis and Summary Tables 4.3 (2004) < http://siteresources.worldbank.org/GDFINT2004/Home/20177154/GDF_2004\%20pdf.pdf > . Only Belgium, Denmark, Ireland, Norway, Luxembourg, the Netherlands, and Sweden reached the target. Ibid.

45 Note 10 above (referring to Part IV of the GATT, which includes non-reciprocal benefits to developing countries).

46 The UNCTAD originally laid out the principles of the GSP. 'Preferential or Free Entry of Exports of Manufactures and Semimanufactures of Developing Countries to the Developed Countries' UNCTAD, UN Doc TD/97/Annexes (1968). EJ de Hann 'Integrating Environmental Concerns into Trade Relations' in International Economic Law with a Human Face (1998) 307, 309-310, 311 (characteristics of the UNCTAD General System of Preferences). The principle gained a legal basis in the GATT as the 'Enabling Clause' agreed in the Tokyo Round in 1979 in accordance with Part IV. Differential and More Favourable Treatment: Reciprocity and Fuller Participation of Developing Countries, Nov. 28, 1979, L/4903, GATT BISD (26th Supp) (1980) 203. 
host state. ${ }^{47}$ This means that all disputes arising out of foreign investment and all issues relating to the treatment of the foreign investor by the host country should be resolved by the courts or legal authorities in the host state and according to the law of the host state. ${ }^{48}$ The foreign investor, in other words, must agree that it will submit to the jurisdiction of its host state in all matters relating to the investment and that it will forego whatever assistance may be available to it as a citizen of its home state.

Similarly, the proponents of the NIEO sought to increase developing country access to new technologies on equitable terms. This was specified in UN resolutions and was the premise underlying the unsuccessful effort to draft a Code of Conduct on transfers of technology. ${ }^{49}$ This Code sought to create a more equal balance of power between the owners of technology and those who need access to it. This can be seen in the Code's support for compulsory licensing and for efforts to regulate transfers of technology.

The opponents of the NIEO argued that IDL should not create special rights for some states and special responsibilities for others. They maintain that, at least from a legal perspective, all states are equal and their rights and duties do not vary according to their level of development. They add that this legal equality does not preclude states from voluntarily agreeing to assume different obligations depending on their level of development and argue that while individual states may wish to grant developing countries preferential treatment, there is no legal obligation for them to do so. ${ }^{50}$ This, they maintain, is the situation with regard to aid.

47 This position is reflected in the Draft UN Code of Conduct on Transnational Corporations and the UN Charter on Economic Rights and Duties of States. UN Economic Charter (note 13 above) art 2.2 (states have sovereign right to control foreign investment within their jurisdictions and that foreign investors shall not intervene in internal affairs of their host state): Draft Code on Transnational Corporations (note 37 above) art 55 ('Entities of transnational corporations are subject to the jurisdiction of the countries in which they operate'). SR Chowdhury 'Legal Status of the Charter of Economic Rights and Duties of States' in Kamal Hossain (ed) Legal Aspects of the New International Economic Order (1980) 79, 88 (noting that Article 2 of the Charter is regarded as 'a classic restatement' of the Calvo Clause, which rejects the use of independent international tribunals to resolve investment disputes).

48 UN Economic Charter (note 13 above) art 2.2 ("Each State has the right: (a) To regulate and exercise authority over foreign investment within its national jurisdiction in accordance with its laws and regulations and in conformity with its national objectives and priorities'); Kelly (note 37 above) 143 (the Charter and the Declaration are intended to ensure a state's sovereign economic right, including the right to freely formulate the policy regime applicable to foreign investors).

49 UN Economic Charter (note 13 above) art 13.2 ("all States should facilitate the access of developing countries to the achievements of modern science and technology, the transfer of technology, and the creation of indigenous technology for the benefit of the developing countries'). See also note 39 above (referring to proponents' attempts to create the International Code of Conduct on the Transfer of Technology).

50 NIEO opponents find confusion between 'legal obligations' and 'political objectives' in the proponents' arguments for the NIEO and attempt to distinguish the former from the latter. Bulajić (note 27 above) 229. From this perspective, states agree to give development assistance or to establish a new international investment regime as a 'political objective', but not as a 'legal obligation'. Ibid. 
In the case of foreign investment the opponents of the NIEO suggest that there are no such voluntary agreements. Consequently, all states must treat each other and their citizens according to standards that are universally applicable and internationally enforceable. They contend that international law requires all states to observe certain minimum international standards in their treatment of foreign investors, regardless of how they treat their own citizens. ${ }^{51}$ These standards require host states to grant foreign investors non-discriminatory treatment, to respect their contractual and property rights and, if they interfere with these rights, promptly to pay the injured party adequate and effective compensation. ${ }^{52}$ In addition, opponents of the NIEO maintain that these standards should be enforceable either through international forums or through the efforts of the injured party's home state. ${ }^{53}$

It is interesting to note that the position of the opponents is, effectively, that IDL should be seen as merely a subset of international economic law. The latter is concerned with all international economic relations and, therefore, includes the economic relations of developing countries.

\section{(ii) Sovereignty and IDL}

Both proponents and opponents of the NIEO agree that the state is the key subject of IDL. Both are concerned with the rights and duties of states and attach great importance to the concept of state sovereignty. This is not surprising, given that proponents are primarily motivated by their interest in achieving economic independence or self-determination for developing countries, or, more specifically, for the state in these countries. Similarly, opponents base their position on classical principles of international law, in which the state is the key subject. ${ }^{54}$ Consequently,

51 Bulajić (note 27 above) 230-31 (developed countries oppose the NIEO as disregarding recognised legal principles including international minimum standards to protect foreign private property and investment rights).

52 UNCTC Report (note 37 above) 35 (some states insisted on including in the Code of Conduct on TNCs 'the payment of prompt, adequate and effective compensation' in accordance with international law); Bulajic (note 27 above) 231 (the idea behind opponents' legal arguments are the following four traditional principles of international law: (1) freedom of contract, (2) pacta sunt servanda, (3) protection of foreign investor's property, and (4) peaceful settlement of economic disputes); Kelly (note 37 above) 144-47 (discussing developed countries' strong concern about discrimination against transnational corporations in creating the Code of Conduct on Transnational Corporations).

53 UNCTC Report (note 37 above) 36 (some states opted for dispute settlement in countries other than the host state and demanded to include specific reference to international arbitration); OECD Guidelines (note 19 above) art I 9 ('The use of appropriate international dispute settlement mechanisms, including arbitration, is encouraged as a means of facilitating the resolution of legal problems arising between enterprises and host country governments.'); Chowdhury (note 47 above) 87-88 (opponents' attempts to amend Article 2 of the Economic Charter to authorise appeals on investment disputes to international forums after parties have exhausted domestic remedies in the host state).

54 Eg. I Brownlie Principles of Public International Law 4 ed (1990) (the principles of the sovereignty and equality of states are the fundamental doctrines of the law of nations). 
they share their opponent's' interest in upholding the principle of state sovereignty. One example of this shared concern with state sovereignty is that both acknowledge the significance of the principles of a state's permanent sovereignty over its natural resources and self-determination. ${ }^{55}$

The importance both sides attach to state sovereignty is consistent with their adherence to the traditional view, with its clear division between the economic and non-economic aspects of development. In this traditional view the sovereign retains final decision-making authority over the noneconomic aspects of development. While both sides recognise that the sovereign should also have substantial influence over the economic aspects of development, they disagree about the extent of that influence. The proponents of the NIEO argue that under international law the sovereign has almost plenary powers ${ }^{56}$ while the opponents contend that international law imposes certain constraints on the state's economic power. ${ }^{57}$ These constraints arise whenever the sovereign chooses to allow foreign investors to operate within its territory.

While the two sides agree on the importance of state sovereignty, they differ on the relative weight they assign to it in their relationships with private economic actors. The proponents of IDL believe that state sovereignty is the most important legal protection that economically and politically weak developing countries have against undue interference by the richer northern countries. They believe that the rights of foreign property owners must take second place to the needs of their host states to protect their sovereignty and to promote the development of their citizens. Thus they insist on the state's ability to submit all economic activity within its borders to its exclusive jurisdiction. They also argue that they can compel these private property owners to surrender some of their property rights for the greater good. This can be seen, for example, in their advocacy of compulsory licences, and in their view that compensation for nationalised property need only be appropriate under

55 Bulajic (note 27 above) 262-63 (the right to economic self-determination and permanent sovereignty over natural resources is regarded as fundamental in international law and the principle of sovereign equality in states' economic relations emanates from and is applied to the right to self-determination without controversy); note 7 above (the Declaration on the Permanent Sovereignty over Natural Resources and its evolution from the principle of selfdetermination).

56 UNCTC report (note 37 above) 17 (proponents considered the principle of permanent sovereignty over natural resources and economic activities well recognised in international law and UN resolutions): Kelly (note 37 above) 148-52 (examining developing countries' attempts to ensure states' power over transnational corporations including 'full exercise by the home country of its permanent sovereignty over all its wealth. natural resources and economic activities').

57 Eg. UNCTC Report (note 37 above) 17 (some states insisted on including a reference to international law in Article 6 of the Draft Code on Transnational Corporations to qualify the states' sovereign power over foreign investors). 
the circumstances and should be determined by the domestic law in the courts and other available forums of the host state. ${ }^{58}$

The opponents of the NIEO, on the other hand, believe that while state sovereignty is important as the basis for the international legal order, it does not empower the state freely to override the rights of private property owners. They argue that there are certain international legal standards that constrain the state's ability to treat foreign property owners in any way that it wishes. ${ }^{59}$ Moreover, they deny that sovereignty can shield the state from all outside intervention in its internal economic affairs. Whenever the state treats foreign investors in ways which are incompatible with international legal standards, other states can demand compensation for the injury to their nationals and can seek to hold the state accountable for its actions. ${ }^{60}$

The opponents also disagree with the proponents of the NIEO over the validity of taking the level of a state's development into account when deciding on its rights and responsibilities. They argue that all states are equal and should be treated equally and that the level of a state's development is not relevant to its status as a sovereign state under international law. Furthermore, they contend, justice requires that all states be treated equally and this means that the same rules should apply in the same way to all of them. This position is consistent with the basic international legal principle that all states are, formally, co-equal sovereign states. ${ }^{61}$

The proponents, on the other hand, argue that, in fact, all states are not equal, and that the pre-NIEO international legal standards do not

58 Chowdhury (note 47 above) 88 (developing countries' rejection of independent international tribunals to resolve investment disputes): Kelly (note 37 above) 143-44 (from the perspective of developing countries, Article 2.2 of the UN Economic Charter is regarded as a principle of appropriate compensation under the domestic law of the expropriating state).

59 The opponents' position is reflected, for example, in the following provisions of the OECD Guidelines: 'Governments have the right to prescribe the conditions under which multinational enterprises operate within their jurisdictions, subject to international law.' OECD Guidelines (note 19 above) art I, 7. 'Governments adhering to the Guidelines set them forth with the understanding that they will fulfil their responsibilities to treat enterprises equitably and in accordance with international law and with their contractual obligations' Ibid art I, 8. See also note 51 above and the accompanying text (opponents' adherence to certain minimum international standard in treating foreign investors and their properties).

60 Note 52 above (dealing with opponents' adherence to international legal principies such as pacta sunt servanda, and prompt, effective, and adequate compensation); note 58 above and the accompanying text (opponents' arguments for resolution of investment disputes in international tribunals).

61 Brownlie (note 54 above): OECD 'Declaration by the Governments of OECD Member Countries and Decisions of the OECD Council on International Investment and Multinational Enterprises' 21 June 1976 in International Investment (Rev ed 27 June 2000) II.1 (member states should give another member country or its nationals 'national treatment' which is "consistent with international law and no less favourable than that accorded in like situations to domestic enterprises'). The Declaration further states '( $t$ )hat Member countries will consider applying "national treatment" in respect of countries other than Member countries', ibid at II.2. 
result in equal treatment. Consequently, the application of the same law to two countries at different levels of development will produce very different results. For example, because of the legacy of colonialism, the application, in unmodified form, to developing countries of principles like non-discriminatory trade treatment or minimum standards for foreign investors can lock them into their historically unequal economic relations. Consequently, they argue that the only way in which to achieve justice is to account explicitly for the differences in situations of countries, which inevitably leads to developing countries obtaining more favourable treatment. ${ }^{62}$

Finally, proponents of the NIEO, at least in principle, see a great role for the state as the engine of development. It decides on the regulatory framework within which economic transactions take place, and it makes most important policy decisions, including what role private and foreign investors will play in the economic development of the country. The opponents of the NIEO, on the other hand, tend to assign a smaller role to the state and a larger role to private actors, particularly the owners of capital, in economic development.

\section{(iii) The relationship between national and international law}

The significance of state sovereignty to the proponents of traditional IDL implies that they see a sharp distinction between national and international law. This is the case even though they differ over the relationship between the two in the regulation of domestic economic affairs. The supporters of the NIEO see IDL as protecting the state's freedom of action in the domestic economic realm. The opponents see international law as imposing some constraints on the state's treatment under domestic law of foreigners involved in the domestic economy.

\section{(iv) The role of international human rights law in IDL}

Proponents of traditional IDL do not view international human rights law as playing an important role because they view IDL as being about economic matters. As discussed above, they treat the legal issues related to the social, environmental, cultural and political aspects of development as external to their economic concerns. Consequently, they regard International Human Rights Law as dealing with issues that, while important, are external to the economic concerns of IDL.

62 Hossain (note 13 above) 5-6 (in NIEO instruments, developing countries attempt to seek legal protection from coercive forces and affirmative action to remedy disadvantageous conditions); Kelly (note 37 above) 150 (from developing countries' standpoint states may give preferential treatment to their nationals in seeking to achieve certain national economic and developmental goals). 


\section{(c) The modern view of development}

The modern view of development tends to be held by NGOs, civic organisations, and progressive elements in governments, corporations, and international organisations.

The proponents of this view argue that the economic aspects of development cannot be separated from its social, political, environmental and cultural aspects and that, in fact, development should be seen as one economically, politically, socially, culturally and environmentally integrated process. $^{63}$ From this perspective, development projects and policies should be treated not so much as discrete economic events but as episodes of social, economic and environmental transformation that are part of an ongoing process of change. This means that to assess fully the desirability of a particular project or policy proposal it is necessary to account for all the ways in which the project will affect the social and physical environment in which it is to be located and how this impact will evolve during the life cycle of the project or policy. Without all this information the decision-makers cannot be confident that they understand the economic, financial, environmental, social, cultural and political consequences of their decisions. They also cannot assess accurately all the costs and benefits of any proposed project or policy thereby increasing the risk that they will approve projects or policies which will produce fewer benefits than anticipated and cause more harm than expected.

The modern view of development is, in part, a response to the mounting empirical evidence that in too many cases governments and project sponsors have so underestimated project and policy costs and overestimated their benefits that they have mistakenly followed policies and constructed (and continue to construct) developmentally harmful projects. ${ }^{64}$

It is also, in part, a consequence of two other factors in human affairs. ${ }^{65}$ The first is our growing recognition of the limits on the ability of the environment to maintain the human societies that we have

63 Note 16 above and the accompanying text (discussing the modern view of multidimensionality of development).

64 RF Mikesell \& L Williams International Banks and the Environment (1992) (several case studies in which poor assessments of projects costs have resulted in excessive environmental costs); B Rich Mortgaging the Earth: The World Bank, Environmental Impoverishment, and the Crisis of Development (1994) (the World Bank's often destructive environmental and political impact on millions of people); B Morse \& TR Berger Sardar Sarovar: The Report of the Independent Review (1992) (describing how Sardar Sarovar projects, which faced resistance from tribal peoples living in the project area, have adversely affected these peoples).

65 A third important factor is improvements in information and communication technology. This technology enables business, investors, and NGOs around the world quickly to learn about and react to developments around the world. Grossman \& Bradlow (note 17 above) 11. This factor receives less attention in this paper because, to date, it has had less direct impact on IDL than the other two. 
created. ${ }^{66}$ This has led to increasing importance being attached to the assessment of all the environmental impacts associated with human activity. It has also resulted in more careful attention being paid to identifying the party best able to assume the burden of assessing the environmental consequences of the proposed activity. The modern view seeks to place the responsibility for assessing the environmental impact on the party undertaking the action that will cause the likely impact. As a result, many project stakeholders are demanding that project sponsors or policy advocates account for all the human and physical environmental costs and benefits of their proposed projects or policy before the project or policy is approved. This is a significant change from the traditional view, which assigned this responsibility to the sovereign and allowed all other actors to defer to the sovereign's decision in this regard.

The operational expression of this demand is the importance attached to impact assessments in planning ${ }^{67}$ and to the growing acceptance of the precautionary principle, which was developed in response to the fact that scientific certainty often comes too late to design effective legal and policy responses to prevent potential environmental threats. It shifts the burden of scientific proof necessary for triggering policy responses from those who would prohibit a harmful activity to those who want to initiate or continue the activity.

The second development is the increasing influence of international human rights law and forums around the world. The development of international human rights law has educated governments and international organisations about their responsibilities towards those who are affected by their actions; raised awareness among people about their rights; and increased their willingness to take steps to oppose development projects and policies that they believe will harm them. The existence of new international mechanisms for raising human rights claims means that it is now possible for many of those who are adversely affected by development projects to challenge these projects in an international forum where they can obtain an 'on the record' hearing. It is also becoming possible for people who are adversely affected to seek to hold accountable those who actually took or helped the perpetrators take the

66 D Hunter et al 'Introduction' in D Hunter, J Salzaman \& D Zaelke (eds) International Environmental Law and Policy (1998) v-vi ('human economic activity threatens to surpass the ecological limits of the biosphere (if it has not already done so in certain instances)').

67 Convention on Environmental Impact Assessment in a Transboundary Context, 25 February 1991, (1991) 30 ILM 802 (hereinafter Espoo Convention) (entered into force 10 September 1997) ('Mindful of the need and importance to develop anticipatory policies and of preventing, mitigating and monitoring significant adverse environmental impacts in general and more specifically in a transboundary context'); Hunter et al (note 66 above) 360; 366 (environmental impact assessment as the "process for examining, analyzing and assessing proposed activities, policies or programs to integrate environmental issues into development planning and maximize the potential for environmentally sound and sustainable development'). 
action that caused the harm. For example, people who feel they have suffered material harm because the World Bank has not followed its own operating rules and procedures can file a Request for Inspection with the World Bank's Inspection Panel. ${ }^{68}$ Similarly, groups that feel that development projects are violating their human rights may be able to file claims before such bodies as the African or Inter-American Human Rights Commissions. ${ }^{69}$ In addition in some cases, domestic courts in the project sponsor's or contractor's home state have been willing to consider these cases. ${ }^{70}$ Regardless of the outcome of the proceedings in these forums, the mere fact that the cases have been filed can impose reputational and financial costs on project sponsors, contractors and the governments which approved the project. The increased costs can be sufficient to change the calculus of the project's costs and benefits.

The result is that, in addition to public interest groups, some in the corporate sector are calling for all the key actors to take more account of human rights considerations in their project planning ${ }^{71}$ and a number of corporations have been willing to work with the United Nations to develop norms of conduct for multinational corporations. ${ }^{72}$

Several consequences follow from this view of development and can be seen most clearly in the case of development projects. The first is that project sponsors and contractors have greater and more complex responsibilities than those assigned to them by proponents of the traditional view of development according to which they are only responsible for carrying out their specific project related functions. The modern view sees them as responsible both for the performance of these functions and for the impact of these functions on the other stakeholders in the project and on the project's physical and human environment. This means that it is no longer seen as acceptable for project sponsors or contractors to treat social and environmental costs as externalities. They are now expected to internalise these costs and account for them in their

68 DD Bradlow 'International Organisations and Private Complaints: The Case of the World Bank Inspection Panel' (1994) $34 \mathrm{Va} \mathrm{J} \mathrm{Int} \mathrm{L} \mathrm{553,} \mathrm{553-54} \mathrm{(function} \mathrm{of} \mathrm{the} \mathrm{Inspection} \mathrm{Panel} \mathrm{as} \mathrm{a}$ forum in which non-governmental parties can hold an international organisation directly responsible for the harm resulted from the violation of its own rules and procedures). IFI Shihata The World Bank Inspection Panel: In Practice (2000) (the objectives and mechanism of the Inspection Panel and its operation); The Inspection Panel Accountability at the World Bank: The Inspection Panel 10 Years On (2003).

69 For details of the function of these human rights commissions, H Hannum (ed) Guide to International Human Rights 3 ed (1999) 11-14 (methods by which international human rights obligations can be enforced); LA Malone \& S Pasternack Defending the Environment: Civil Society Strategies to Enforce International Environmental Law (2004).

$70 \mathrm{Eg}$, Jota v Texaco, Inc. $157 \mathrm{~F} 3 \mathrm{~d} 153$ (2d Cir. 1998) (consolidated appeals of two class actions brought by residents of Ecuador and Peru against Texaco in New York for environmental and personal injuries allegedly caused by Texaco's exploitation of oil fields in a river basin in Ecuador).

71 This can be seen, for example, in the adoption of corporate codes of conduct and in the increasing attention being paid to the issue of corporate social responsibility.

72 The Global Compact <http://www.unglobalcompact.org > 
project planning. In other words, it is no longer considered prudent, in an economic or risk management sense, for project contractors to rely on government decisions relating to environmental and social matters.

The second consequence, which follows from the first, is that proponents of this view of development attach great importance to consultations between those who make the decisions about projects and those who will be affected by them. The reason is that the project decision-makers can only be confident that they have accurately assessed the costs and benefits of the project if they understand how those who the project will affect will react to it and to the resulting changes in their social and physical environment. This information can only be uncovered by consultation with all parties who will be affected or with those who have the ability to influence how these affected parties will respond to the project.

The emphasis on consultation has two important implications. The first is that the consultation process can only produce the desired result if decision-makers provide the affected people with adequate information about the project. Unless they have sufficient information to understand the potential impact of the project, they cannot know with any confidence how they will respond to it. The need for consultation, therefore, necessarily leads to a requirement for disclosure of information. $^{73}$

The need for consultation also has the effect of partially localising the focus of the project. ${ }^{74}$ Under the traditional view of development, project sponsors and contractors only need to consult the relevant regulatory authorities, usually national authorities, in the course of making projectrelated decisions. Now, however, they must pay greater attention to local concerns and impact, even if the project's ultimate rationale is to provide national or even transnational benefits. This necessarily has the effect of empowering local stakeholders and their representatives in their consultations with the project sponsors. In this regard, it is important to note that the modern view highlights the importance of consulting groups traditionally excluded from power, such as women and indigenous people. Since both these groups have the ability to influence the future impact of the project and its likely success they cannot be ignored in the consultation process.

This consequence of the modern view has legal implications. It suggests that for sustainable development to occur attention will need to be paid to removing legal barriers that might impede the ability of concerned groups to participate in the consultation process. These barriers could

73 JB Battle et al Environmental Decisionmaking and NEPA 2d ed (1994).

74 Note that this is taking place at the same time as the regulatory framework for projects is being globalised. For example, World Bank and IFC Safeguard Policies, < http://www.worldbank. org $>$ and < http: $/ /$ www.ifc.org $>$. 
include both overtly discriminatory laws ${ }^{75}$ and legal measures that have the effect of inhibiting these groups from participating in the consultations. ${ }^{76}$

Another implication is that consultations necessarily politicise the project because both the disclosure of information and the actual consultations become part of the project sponsors' efforts to secure the support of the affected stakeholders for the project. If the affected people do not support the project, decision-makers cannot be confident that they will act in the best long-run interests of the project and that, in fact, it will be sufficiently sustainable to produce the expected benefits or that it will have the predicted impact. Consequently, the consultations become an important arena of contest between those who support and those who oppose the project, in which each group seeks to use the consultations to advance its particular position.

Projects can also be politicised in another way if there are differences of opinion between the local stakeholders and the national government or project sponsors over the desirability of the project. In such a case the sponsors and contractors will need to choose how to respond, clearly forcing them to take a position on a domestic political issue.

The modern view of development requires a more participatory form of decision-making than does the traditional view. The reason is that if people do not feel that they are able to influence the decision-making process they are unlikely to be either confident or willing to take part in the consultation process. This, in turn, means that project decisionmakers who insist on a top-down form of decision-making are unlikely to obtain all the information they need to anticipate and fully assess the potential impact of the project. ${ }^{77}$

A third consequence of the modern view is that it has begun to blur the boundaries of the sponsors' or contractors' responsibilities. In the traditional view, the scope of these responsibilities is relatively well

75 Examples of such measures would be laws that deny women the right to participate in meetings and laws that do not recognise the property rights of indigenous people or women.

76 Examples of such measures could include laws that require all documents to be submitted in one official language rather than in the languages of indigenous peoples; laws that deprive people of their internationally recognised rights to free speech and association; the protection of the integrity of their person and the failure of some governments effectively to enforce their laws against certain social groups who take action to limit participation in development by other groups.

77 Eg, World Bank The World Bank Participation Sourcebook (1996) 3-4 (critically analysing project planning with the conventional 'external expert stance' in which sponsor and designers collect information by using experts but may fail to listen to the voices of local stakeholders or disadvantaged people) <http://www.worldbank.org/wbi/sourcebook/sbhome.htm >. The Bank currently advocates stakeholder participation that involves all parties concerned, such as the poor and socially disadvantaged, NGOs, private sector organisations, local and national government officials, and Bank staff. Ibid 6-7. For examples of participatory development, ibid 17-120 (reviewing development projects with participatory approaches in sixteen countries). 
defined. Geographically, it is limited to the discrete location of the project and, more specifically, to those aspects of the project for which the sponsors or contractors have been directly responsible. Furthermore, the responsibilities have relatively clear temporal boundaries. The sponsors and contractors are responsible for events that happen during the time they are working on the project site and for problems that develop as a direct result of their work for a defined period thereafter. ${ }^{78}$ Their responsibilities will only be ongoing if they continue to be involved in the operation and maintenance of the project after construction is completed.

The modern view requires all project sponsors and contractors to take into account the impact of the project and how this impact will evolve during the life cycle of the project. Since all aspects of the project are seen as inter-connected, the sponsors and contractors cannot easily divide responsibility amongst themselves. This makes it harder to identify the limits of their responsibility. In addition, the modern perception of a project requires sponsors and contractors to account for and take responsibility for any impact the project may have both during its construction and for the period thereafter in which its impact is socially or environmentally significant. In fact, the modern vision of development is that any attempt to draw boundaries around the project sponsors' and contractors' responsibilities is a question of judgment and, therefore, requires debate and consultation.

The significance of the difference between the perceptions of responsibility in the two views can be seen in the case of a dam. In the traditional view the scope of the sponsors' and contractors' responsibility is limited to their direct contribution to the dam itself and its immediately surrounding areas. The duration of their responsibility is limited to the time of their involvement in the dam project and for a defined period thereafter. On the other hand, the modern view holds the dam's sponsor and contractors responsible for the social, economic, cultural, political and environmental impact on the whole river basin; the impact on all who depend on the river basin and the way this impact will evolve over the period of the dam's construction, operation and decommissioning. Their responsibility may also continue during the period in which the environment and the affected people adapt to the decommissioning of the dam.

The changing view of sponsor and contractor responsibility is relevant to the issue of the treatment and the responsibilities of foreign investors. Foreign businesses could, at one time, feel relatively confident that they had met all their legal obligations if they acted in conformity with the national law of their host countries. However, the changing scope of their

78 The period for which the project sponsors and contractors remain liable for damage may be set by contractual warranties of by statute or may depend on their ongoing relationship with the project. 
responsibilities begins to call this into question. First, as the example of the dam project suggests, the project may have an impact outside the borders of the state in which it is located and the project sponsor must incorporate this possibility into its planning. This means that it will need to pay attention to the international and national law that may be applicable to these 'extra-territorial' effects.

In addition, it may not be sufficient for businesses to be complacent if the host state law does not deal adequately with particular issues. The reasons are developments in communications and the existence of international forums in which people adversely affected by projects can bring claims. These make it possible for the affected people to claim, either in a legal forum or in the 'court' of public opinion, that the project sponsor or contractor is liable for their suffering because it did not follow the best standards of regulation in the industry/world. The latter, while it will not be a winning legal argument, can be a powerful moral argument that can cause significant harm to the reputation of the project sponsor or contractor and can result in real financial cost. Consequently, proponents of the modern view of IDL must take into account these forums and soft law standards in their consideration of IDL's treatment of the rights and responsibilities of foreign investors.

Another consequence relevant to IDL is that the modern view does not show the same respect to the concept of sovereignty as the traditional view. In the traditional view, the sovereign has the final decision over the social, political, cultural and environmental 'externalities' in development projects and policies. In the modern view, these 'externalities' have been 'internalised' and are now part of the responsibility of each of the actors in the development project. Responsible project sponsors, contractors and other project stakeholders are expected to make their own decisions about these 'externalities' even if it places them in conflict with the sovereign. According to the modern concept of development, the sovereign is only one player in the development drama, and there is no clear justification for international organisations, foreign corporations, financial institutions, and NGOs to give its opinions greater weight than those of other participants. In fact, the case for deferring to the sovereign's opinions is particularly weak when these opinions conflict with the expressed interests of those who will be most directly affected by the project.

\section{(d) The modern view of development and IDL}

It should be clear from the above that the 'modern view' of development is more holistic and differs from the traditional view in its understanding of the substantive content of IDL, of sovereignty and of the relationship between national and international law and the role that international human rights law should play. Each of these differences is discussed in more detail below. 


\section{(i) The substantive content of IDL}

The modern view of the substantive content of IDL differs in two important ways from the traditional view. 'Modern' IDL is as concerned with the legal rules and procedures that will lead to development policies and projects that are economically, environmentally, socially and legally sustainable as it is with the rights and responsibilities of developing and industrialised states to each other and to other participants in the international economy. The significance of this difference is that the modern IDL views the state as only one of many actors in the development process, while the traditional view treats the state as the primary actor. This can be seen, for example, in the Declaration on the Right to Development (DRD), which is an important document for modern IDL. ${ }^{79}$ The DRD stipulates that each individual and each group of people has a right to development. ${ }^{80}$ It also makes clear that the state has obligations towards the individual and the group to help him/her/ them develop. ${ }^{81}$ This differs from the traditional view that places the focus on the rights and responsibilities of the state in developing countries in relation to those in industrialised states and those foreign economic actors who are active in or involved with the developing country.

The second difference is that the scope of the modern view is not limited to economic issues. Thus, in addition to international economic law, it incorporates those international environmental and human rights law principles and documents that are relevant to its holistic view of the development process. They include the Universal Declaration of Human Rights, ${ }^{82}$ the major United Nations Human Rights conventions, ${ }^{83}$ the

79 Declaration on the Right to Development (note 16 above) art 2.2 ('All human beings have a responsibility for development, individually and collectively, taking into account the need for full respect for their human rights and fundamental freedoms as well as their duties to the community ...').

$80 \mathrm{Ibid}$ art 1.1 ('The right to development is an inalienable human right by virtue of which every human person and all peoples are entitled to participate in, contribute to, and enjoy economic, social, cultural and political development, in which all human rights and fundamental freedoms can be fully realized.').

81 Ibid 2.3. ('States have the right and the duty to formulate appropriate national development policies that aim at the constant improvement of the well-being of the entire population and of all individuals, on the basis of their active, free and meaningful participation in development and in the fair distribution of the benefits resulting therefrom.').

82 Universal Declaration of Human Rights (1948).

83 International Convention on Civil and Political Rights (1966); International Covenant on Economic Social and Cultural Rights (1966); Convention on the Rights of the Child (1989) (hereinafter CRC); Convention on the Elimination of All Forms of Discrimination Against Women (1980) (hereinafter CEDAW); International Convention on the Elimination of All Forms of Racial Discrimination (1965). See also Vienna Declaration and Programme of Action (1993). 
$\mathrm{DRD}^{84}$, the Stockholm Declaration, ${ }^{85}$ Rio Declaration on Environment and Development (the Rio Declaration), ${ }^{86}$ and such key multilateral environmental agreements as the climate change, and biodiversity conventions. ${ }^{87}$ It is important to note that some of these documents are important to modern IDL even though they may not create legally enforceable obligations.

These documents expand the content of traditional IDL in a number of important ways. The Rio Declaration, for example, seeks to establish principles that promote economic activity that is environmentally and socially sustainable. It stipulates that such important environmental principles as common but differentiated responsibilities, impact assessment, and the precautionary principle are applicable to all these actors. ${ }^{88}$ The principle of common but differentiated responsibilities recognises that the obligations of states may differ according to their level of development and their specific circumstances. The Rio Declaration refers to the fact that while all states may be bound by the same international obligations they may not all have the same capacity to act or may not all be affected in the same way by specific problems and so cannot all make the same contribution to their resolution. ${ }^{89}$ Impact assessments refer to the requirement that all those involved assess carefully the impact of their proposed actions and endeavour to avoid or mitigate any expected adverse environmental and social consequences of such actions. ${ }^{90}$ This, together with the precautionary principle, justifies states and other participants taking preventive action to avoid potentially serious and

84 Declaration on the Right to Development (note 16 above).

85 Declaration of the UN Conference on the Human Environment, 16 June 1972 (1972) I1 ILM 1416.

86 Rio Declaration on Environment and Development (1992) 31 ILM 874 (hereinafter Rio Declaration); Johannesburg Declaration on Environment and Sustainable Development < http://www.un.org/esa/sustdev/documents Johannesburg\%20Declaration.doc > (2002).

87 United Nations Framework Convention on Climate Change (1992) 31 ILM 849 (hereinafter Climate Change Convention); Convention on Biological Diversity (1992) 31 LLM 818 (1992) (hereinafter Biodiversity Convention).

88 Rio Declaration (note 86 above) principle 27 ('States and people shall cooperate in good faith and in a spirit of partnership in the fulfilment of the principles embodies in this Declaration .').

89 Rio Declaration (note 86 above) principles 6-7 (putting priority on '[t]he special situation and needs of developing countries, particularly the least developed and those most environmentally vulnerable' while highlighting developed countries' responsibility in consideration of the burdens they impose on the global environment). The five-year review of UNCED conducted in 1997 highlighted the principle of common but differentiated responsibilities in formulation and implementation of national strategies for sustainable development while calling for the commitment of all parties concerned in both developed and developing countries. Programme for the Further Implementation of Agenda 21, GA Res S19-2, 26 UN Doc A/S19-2 (1997) (hereinafter Programme on Agenda 21).

90 Note 67 above (definition of environmental impact assessment and its application in the transboundary context in Espoo Convention). 
irreversible harm even in the absence of scientific certainty. ${ }^{91}$ The Rio Declaration also makes clear that all actors - states, private enterprises. individuals and groups and international organisations - have a responsibility to protect the environment and to promote development. ${ }^{92}$

The modern view's expansion of the scope of IDL should not be interpreted as implying any diminution in the importance of the international economic law issues that are the core content of the traditional view of IDL. The legal issues raised by practitioners of traditional IDL are still of great interest and relevance to the practitioners of modern IDL and the expansion of the concept of IDL should simply be seen as shifting the emphasis placed on some of the relevant international economic law issues. For example, in the traditional view of IDL, the primary obligation of a foreign investor is always to act in conformity with the law of the host state. In the modern view, the foreign investor's obligation may be broader than this in that it may be required to act in conformity with the "best international practices' in the industry, even if these standards exceed those stipulated by the law of the host state. Furthermore, the foreign investor who fails to act in conformity with the applicable standards may, in fact, be accountable to any individual or group that believes it has suffered or may suffer as a result of the investor's failure to act in conformity with the best international practice.

Interestingly, the forums in which these parties can bring their challenge against a foreign investor may include such bodies as the courts of the investor's home state, the International Finance Corporation's Compliance Advisor/Ombudsman, ${ }^{93}$ the inspection mechanisms at the multilateral development banks ${ }^{94}$ and the various regional and universal human rights courts or commissions. This is in addition to any claims they may have under the host state's domestic law or that the home state may bring on their behalf in an international forum.

91 Rio Declaration (note 86 above) principle 15 ('Where there are threats of serious or irreversible damage, lack of full scientific certainty shall not be used as a reason for postponing costeffective measures to prevent environmental degradation.').

92 Rio Declaration (note 86 above) principle 27 ('States and people shall cooperate in good faith and in a spirit of partnership in the fulfillment of the principles embodied in this Declaration .').

93 For details, see International Finance Corporation, Operational Guidelines for the Office of the IFC/MIGA Compliance Advisor/Ombudsman, <www.cao-ombudsman.org > .

94 In addition to the World Bank, the African, Asian and Inter-American Development Banks, and the European Bank for Reconstruction and Development also have inspection mechanisms. Information on these mechanisms are available at their websites: African Development Bank, <www.afdb.org>: Asian Development Bank, <www.adb.org>; European Bank for Reconstruction and Development, < www.ebrd.org > Inter-American Development Bank, <www.iadb.org >. For a comparative analysis of these mechanisms see DD Bradlow 'Private Complainants and International Organisations: A Comparative Study of Independent Inspection Mechanisms in International Financial Institutions' (2005) 36 Georgetown $J$ of Int $L$ (forthcoming). 


\section{(ii) Sovereignty and IDL}

Both approaches to IDL recognise that states are the pre-eminent actors in the international legal arena and that the state is sovereign within its domestic jurisdiction. However, the modern approach has a much narrower interpretation of 'sovereignty' than does the traditional approach. In fact, the modern approach, with its holistic view of development, sees very few issues as being exclusively within the sovereign's 'domestic jurisdiction'.

This narrow interpretation of the sovereign's exclusive area of jurisdiction is derived from the modern approach to IDL's concern with human rights and environmental issues. It therefore tends to perceive the international community as having a legitimate interest in protecting the interests of groups which claim that they are being mistreated as a result of the development process in a state. ${ }^{95}$ For example, under this rights based approach, the international community can intervene to protect indigenous people, women, and child workers. ${ }^{96}$ Countries that are signatories to international human rights agreements have obligations that the international community may be able to enforce against them in cases of noncompliance. These agreements may also impose non-binding moral obligations that may be de facto enforceable on non-signatory states and other actors in development. The practical effect of this aspect of IDL can be seen, for example, in the efforts of the international community to deny financing to projects such as the Sardar Sarovar dam in India ${ }^{97}$ and the

95 Declaration on the Right to Development (note 16 above) art 6.1 ('All States should cooperate with a view to promoting, encouraging and strengthening universal respect for and observance of all human rights ...): Grossman \& Bradlow (note 17 above) 3 (United Nations's recognition of protection of human rights as an international obligation provides the basis of international organisational supervision over human rights).

96 Declaration on the Right to Development (note 16 above) art 6.1 (States' duty to cooperate in promoting universal human rights 'without any distinction as to race, sex, language or religion'). There are specific UN conventions that cover human rights of women and children. CEDAW (note 83 above); CRC (note 83 above). The UN Commission on Human Rights has also proposed a Draft United Nations Declaration on The Rights of Indigenous Peoples (1994) 34 ILM 541, 546. On child labour, see International Labour Organisation Convention Concerning the Prohibition and Immediate Elimination of the Worst Forms of Child Labour (17 June 1999) $38 I L M$ 1207. In addition to these formal efforts, international civil society has reacted to business practices that fail to incorporate human rights considerations; $P$ Malanczuk Globalization and the Future Role of Sovereign States' in International Economic Law with a Human Face (note 46 above) 45, 58-59 (examples of international protests against Shell for disregard of human rights of minority rights activists in Nigeria and against Nike for unfair labour practices, including the use of child labour, in developing countries).

97 In 1992, in reaction to strong international criticism of the Sardar Sarovar project, the World Bank conducted a review and imposed conditions on the remaining loan to ensure environmental protection and the adequate resettlement and economic rehabilitation of the affected people. In 1993 the Bank formally cancelled the remaining loan. World Bank Operations Evaluation Department, World Bank Learning from Narmada, Precis No 88 (1995). For a detailed review of the Sardar Sarovar Dam project, see Morse \& Berger (note 64 above). 
Ilisu dam in Turkey, ${ }^{98}$ that are seen as impairing the human rights of those adversely affected by them. It can also be discerned in the approach of the Bretton Woods institutions to such projects as the ChadCameroon pipeline ${ }^{99}$ and to good governance and in the debates in the World Trade Organisation (WTO) over labour rights. ${ }^{100}$

The emphasis that modern IDL places on environmental issues also tends to reduce the scope of the state's sovereign jurisdiction. Many environmental issues, such as those affecting international waterways and those dealing with air pollution, do not respect political borders. They can only be addressed within the scope of the boundaries imposed by the affected ecosystem. In many cases this means that they can only be resolved through inter-state agreement and with the cooperation of all those public and private stakeholders whose actions can either help resolve or exacerbate the environmental problem. This means that all the affected states and stakeholders perceive themselves as having an interest in the way in which other states and stakeholders behave with regard to the applicable environmental issues. Since the state is only one of the relevant actors in this regard, the other stakeholders and practitioners of modern IDL tend to attach less significance to state sovereignty than the proponents of traditional IDL and see it as less of a barrier to interference in the internal affairs of another state. ${ }^{101}$ The influence of

98 The export credit agencies of developed countries refused to give export credit support unless Turkey satisfied four conditions designed to address international concerns about the project's adverse impact on human rights and the environment. JM Adams 'Environmental and Human Rights Objections Stall Turkey's Proposed Ilisu Dam' (2000) 11 Colorado J of Int Environmental $L \&$ Policy 173, 175-76. The conditions include the creation of an internationally acceptable resettlement plan, the establishment of an upstream water treatment plant, maintenance of downstream water flow and the protection of archeological sites. Ibid 176.

99 Report of the World Bank Inspection Panel 'Cameroon: Petroleum Development and Pipeline Project (Loan No 7020-CM); and Petroleum Environment Capacity Enhancement (CAPECE) Project' (Credit No 3372-CM) (24 July 2003), < http://wbln0018.worldbank.org/IPN/ ipnweb.nsf/WReport/081ABED76D5636B485256C93005F152A >.

100 Policy Department \& Review Department IMF Review of the Funds Experience in Governance Issues (2001) 8-9 (IMF regards good governance as an important condition for effectively attaining the objectives of IMF-supported projects and promotes it through prior consultations with states seeking assistance) <http://www.imf.org/external/np/gov/2001/ eng/gov.pdf $>$. The IMF highlights the importance of cooperation with other multinational institutions including the World Bank and the OECD to facilitate good governance in the borrowing country. Ibid 20-21. For details of the World Bank's strategies regarding good governance through development assistance, World Bank Reforming Public Institutions and Strengthening Governance (2000), <http://wwwl.worldbank.org/publicsector/civilservice/ Reforming.pdf >; 'Recognised Labour Standards and Trade' in International Economic Law with a Human Face (note 46 above) 79, 80-81 (the use of trade sanctions against states that fail to protect labour rights as a key issue in debates on international trade and labour standards).

101 O Schachter 'The Erosion of State Authority and Its Implications for Equitable Development' in International Economic Law with a Human Face (note 46 above) 31, 36-38 (discussing the active roles played by transnational civil society, including private business, NGOs, and scientific and technical experts, in promoting international development). 
this can be seen in the Rio Declaration ${ }^{102}$ and in such international environmental agreements as the Global Climate Change ${ }^{103}$ and Biodiversity Conventions. ${ }^{104}$ It is also implicated in the Shrimp-Turtle and Tuna-Dolphin cases that were heard by the WTO and GATT dispute settlement bodies. ${ }^{105}$

It is important to recognise that while the modern IDL's narrow approach to sovereignty is derived from human rights and environmental law it also applies to the international economic aspects of IDL. This necessarily follows from its holistic view of development which means that IDL sees the environmental, human rights and economic aspects of international transactions as being too intertwined to be treated separately. ${ }^{106}$ Thus, modern IDL does not see any subset of the issues relating to regulation of foreign investors as being exclusively within the jurisdiction of the host state. In this regard it shares the view of these proponents of traditional IDL who contend that international law requires foreign investors to adhere to certain minimum standards of treatment and behaviour. However, the holders of the modern view of IDL differ from the traditionalists in their view of the range of these standards, arguing that they should apply to a broader range of issues

102 Rio Declaration (note 86 above) principle 10 ('Environmental issues are best handled with the participation of all concerned citizens, at the relevant level.'). The Rio Declaration emphasises participation of women, the youth, and indigenous people and local communities in achieving sustainable development. Ibid principles $20-22$.

103 Climate Change Convention (note 87 above) art 4.1(i) (States shall "(p)romote and cooperate in education, training and public awareness related to climate change and encourage the widest participation in this process, including that of non-governmental organisations').

104 Biodiversity Convention (note 87 above) preamble ('Recognizing the close and traditional dependence of many indigenous and local communities embodying traditional lifestyles on biological resources, and the desirability of sharing equitably benefits arising from the use of traditional knowledge, innovations and practices relevant to the conservation of biological diversity and the sustainable use of its components'). The Convention also stresses women's vital role in maintaining and promoting the sustainable use of biological diversity and recognises the need for women's participation in policy-making and implementation to protect biological diversity. Ibid.

105 WTO Report of the Appellate Body on United States - Import Prohibitions of Certain Shrimp and Shrimp Products, WT/DS58/AB/R (12 October 1998) (hereinafter Shrimp-Turtle case) (United States import ban on shrimp products based on its domestic environmental regulation aiming at protection of sea turtles), <http://www.wto.org/english/tratop_e/ dispu_e/58abr.pdf > ; GATT Dispute Settlement Panel Report on United States Restrictions on Imports of Tuna (1994) 33 ILM 839; GATT Dispute Settlement Panel Report on United States Restrictions on Imports of Tuna (1991) $30 I L M 1594$ (dealing with United States import ban on tuna products from Mexico, which did not introduce dolphin-friendly fishing practices required under United States environmental law). In the Shrimp-Turtle case, several NGOs submitted amicus curiae briefs to support the United States environmental regulation while the appellants (India, Pakistan, Thailand, and Malaysia) argued against the NGOs' submission of amicus briefs. Shrimp-Turtle case (above) 12-13, 18, 28.

106 Rio Declaration (note 86 above) principle 4 ("In order to achieve sustainable development, environmental protection shall constitute an integral part of the development process and cannot be considered in isolation from it.); Programme on Agenda 21 (note 89 above) para 23 ('Economic development, social development and environmental protection are interdependent and mutually reinforcing components of sustainable development'). 
than merely the state's treatment of foreign investors. The standards also include the investor's responsibility to the host state and its citizens and the state's responsibility to the other stakeholders in the investment or business transaction.

The issue of standards is also relevant to the changing ability of the state to regulate activity within its own boundaries. Regulation was formerly a national function in which states would pass laws, and regulations to govern particular forms of conduct in their jurisdictions. Now, however, because economies are becoming globalised, regulation is being internationalised. Today, the effective regulatory framework for a particular sector will, de facto, be derived from a variety of different sources. The first, and still the most important of these, is the laws and regulations of the country in which the project is located. These will be supplemented by the international treaties to which that state is a signatory. In addition, project sponsors and contractors will need to refer to various sources that, while not binding or even directly applicable, give guidance on what constitutes best practice for the particular activity they are undertaking. These sources include international organisations like the World Bank ${ }^{107}$ and the International Finance Corporation (IFC); ${ }^{108}$ the ten principles underlying the United Nations' Global Compact with business $;{ }^{109}$ industry associations like the International Organisation for Standardisation (ISO) $;{ }^{10}$ and individual corporate codes of conduct. ${ }^{11}$ The sum of all these different sources can be considered the effective

107 G Loibl 'The World Bank Group and Sustainable Development' in International Economic Law with a Human Face (note 46 above) 513, 520-25 (The Bank's operational policies and procedures relevant to environmental protection and sustainable development). For a comprehensive list of the Bank's operational manuals, see World Bank, Operational Manual: Table of Contents, <http://wbln0018.worldbank.org/institutional/manuals/opmanual.nsf > .

108 For a list of relevant guidelines, see Environment Division, IFC Environmental, Health and Safety Guidelines, < http://www.ifc.org/enviro/enviro/pollution/guidelines.htm. > . Projects supported by the IFC are also subject to relevant parts of the Bank`s Operational Manuals. IFC, Safeguard Policies (listing relevant operational manuals), <http://www.ifc.org/ifcext/enviro.nsf/Content/ Safeguardpolicies $>$. It should be noted that these policies are currently undergoing review and are likely to be replaced in the near future. For information see the IFC website.

109 The Ten Principles of the Global Compact, <http://www.unglobalcompact.org/ > The ten principles include two dealing with human rights, four dealing with labour rights, three dealing with the environment and one dealing with corruption.

110 The ISO introduced a series of quality management standards (ISO 9000). ISO, ISO 9000 and ISO 14000 in Plain Language, < http://www.iso.org/iso/en/iso9000-14000/index.html> and created a series of environmental management standards (ISO 14000) to address the following issues: environmental management systems, environmental auditing and related investigations, environmental labels and declarations, environmental performance evaluation, and life-cycle assessment. Tech Comm 207 ISO, What is ISO 14000?, <http:// www.tc207.org/faq.asp?Question $=2>$.

111 Eg, Levi Strauss \& Co Social Responsibility/Global Sourcing and Operating Guidelines (corporate guidelines taking into account environment, labour, and human rights issues in business partners and the host country), <http://www.levistrauss.com/responsibility/ conduct/guidelines.htm > Nike Inc Labour Code of Conduct ('zero tolerance for under-age labour'), <http://www.nike.com/nikebiz/gc/mp/pdf/English.pdf >; Shell Oil Co Our Policy and Principles (information on Shell's corporate policy regarding business principles, health and environment, and sustainable development), <http://www.countonshell.com $>$. 
regulatory framework for a particular project because participants who fail to act in conformity with the best practices established by this collection of laws, regulations, guidelines, and examples of good conduct risk incurring reputational and moral damages, if not legal liability. ${ }^{112}$ In this sense they form an effective regulatory framework that informs the modern view of IDL's position on the rights and responsibilities of foreign investors.

\section{(iii) The relationship between national and international law}

As we saw above, the traditional view of IDL is based on a strict delineation between national and international law. The modern approach, on the other hand, tends to soften the distinction between the two. In fact, the modern approach to IDL is premised on a form of transnational law in which the boundary between national and international legal issues is blurred and there is a dynamic interaction between them. This can be seen, for example, in the ways in which issues such as climate change need to be addressed at both international and national level. It can also be seen in the expansion of the effective regulatory framework for foreign investors. This shift to transnational law is consistent with the general trend in this era of globalisation towards a reduction in the de facto significance of national boundaries.

\section{(iv) The role of international human rights law in IDL}

International human rights law plays an important role in modern IDL because of the need to provide legal support for a holistic vision of development. Thus IDL is striving to develop doctrines and principles that integrate those of International Human Rights Law with those of International Environmental Law and International Economic Law.

The DRD is a document of particular importance to IDL. Its emphasis on the human person, individually and collectively, as the subject of development ${ }^{113}$ helps structure the normative framework of IDL. In addition, the fact that it stresses both the responsibilities of states to create conditions favourable for the realisation of the right to development ${ }^{114}$ and the right of all human beings to development ${ }^{115}$ provides a principled basis for modern IDL's concern with the rights and responsibilities of all participants in the development process. Finally, the

112 The hydro and mining sectors are good examples of sectors where the regulatory framework has been effectively globalised. In both the conflict generated around major projects resulted in sector-wide reviews that attempted to establish general principles to guide conduct in the sector.

113 Declaration on the Right to Development (note 16 above) art 1.1.

114 Ibid arts $3.1,6.3$, and 8.1 .

115 Ibid art 2.2. 
DRD's admonition that states should encourage '...popular participation in all spheres as an important factor in development ... ${ }^{116}$ provides legal support for the insistence of the modern view of development on the importance to the development process of participation.

Because modern IDL seeks to establish the legal principles on which to base a holistic approach to development, it has an interest in attempts to operationalise human rights. For this reason, IDL views the reports of the World Commission on Dams as important documents with the potential to influence the future evolution of IDL. ${ }^{117}$

\section{SOMe Thoughts on the Future Evolution OF INTERNational DEVELOPMENT LAW}

There is a certain irony about the way in which IDL has evolved. Its early proponents were interested in helping developing countries overcome the economic legacy of colonialism and strengthen their control over their economic future. In this sense their primary goal was to strengthen the economic sovereignty of developing countries by enhancing the state's ability to manage its economy. Consequently, they were interested in evolving rules that required foreign investors and other economic actors to respect the law, rules and procedures of their host states; providing legal support for the unilateral modification of unfair economic agreements; and encouraging industrialised countries to provide financial and other economic support for developing countries. These objectives also informed the work of the advocates of the NIEO.

The proponents of the modern approach to IDL are, in some ways, working to undo the gains made by those who advocate the traditional approach. While they recognise the importance of state sovereignty in a world of economically and politically unequal states and of enhancing the ability of developing countries to shape their own destinies, ${ }^{118}$ they are also seeking to enhance the power of non-state actors in the development process. This follows from their incorporation of human rights and environmental issues into IDL and their attempts to use human rights and environmental law to constrain the state's ability to impose development policies and projects on its subjects. Similarly, they are seeking to require all stakeholders, including the state and foreign

116 Ibid art 8.2

117 World Commission on Dams Dams and Development: A New Framework for Decision Making (Earthscan 2000).

118 Schachter (note 101 above) $43-44$ (the present state-based structure still constitutes the general framework of governance in international relations, although noting the increasing influence of non-state actors); Rio Declaration (note 86 above) principle 2 ('States have, in accordance with the Charter of the United Nations and the principles of international law, the sovereign right to exploit their own resources'); Climate Change Convention (note 87 above) preamble ('Reaffirming the principle of sovereignty of States in international cooperation to address climate change'). 
economic actors, to respect the rights of all other stakeholders in each society's development process.

In one important respect these two approaches are less incompatible than it might appear. They share an interest in empowering the poorer and weaker actors in the international economic order and they are both interested in creating incentives for the richer and stronger player to be more responsive to the needs of weaker stakeholders and to surrender some of their control over the international economic order. They differ, however, on who should be the beneficiaries of this effort and at whom it should be targeted. The traditional approach sees the problem primarily in terms of states as beneficiaries and targets. The modern approach prefers to focus on individuals and communities as the beneficiaries and relatively powerful states, corporations and international organisations as the targets.

For several reasons, the current global climate suggests that the future will favour the modern approach to development and IDL. First, the phenomenon of globalisation is weakening the de facto control of all states over the economic and political affairs of their countries. It is also creating conditions that, at least in relative terms, empower private nonstate actors, regardless of whether they are commercial enterprises or non-governmental organisations representing civil society, at the expense of the state. This suggests that IDL principles that rely too heavily on exclusively state-based approaches to resolving development issues risk being overtaken by events.

Second, there is growing concern around the world about environmental issues and about the sustainability of our current approach to economic development. This suggests that approaches to IDL that do not take into account the need to promote environmental responsibility and sustainable development are likely to be viewed as out of step with the needs of our time. In this regard it is important to note that an element of environmental law that is often overlooked is its attempt to promote more responsible consumption habits, particularly in the richer countries. ${ }^{119}$

Third, the dramatic developments in telecommunications make it increasingly difficult for key decision-makers to control the flow of information about their activities and, therefore, the responses to these activities. This means that neither states nor large corporations can maintain exclusive control over those activities for which they are presumed to be responsible. This breakdown in control is challenging

119 Rio Declaration (note 86 above) principle 8 ('To achieve sustainable development and a higher quality of life for all people, States should reduce and eliminate unsustainable patterns of production and consumption ...); Programme on Agenda 21 (note 89 above) 28 (stating that unsustainable patterns of consumption in developed countries continue to exacerbate environmental degradation and that developed countries should make an effort to change their unsustainable consumption patterns). 
legal thinkers to design new approaches to regulation and to hold those involved accountable for the consequences of their actions. ${ }^{120}$ This means that an approach to IDL that is focused too much on the state and its powers and responsibilities risks being found wanting in its proposed solutions to developmental problems.

The result is that, increasingly, even its proponents are finding the traditional approach to IDL inadequate. They are learning that its insistence on an economic focus does not help states, businesses, communities or individuals understand their de facto rights and responsibilities with regard to development activity and exposes them to unacceptable risks of harm or liability. For example, it leads foreign investors to think that it is sufficient to comply with their host states' domestic legal requirements in relation to environmental and social responsibilities, regardless of whether these requirements comply with international 'best practice' as embodied in such soft law as World Bank Operational Policies and industry standards. The result is that investors may misconstrue their de facto responsibilities and underestimate their exposure to reputation risk and to financial liability. Similarly, it leads them to underestimate the importance of public participation in their project-related decision-making, which can also lead them to assess incorrectly the risks to their ventures.

As a consequence of these acknowledged inadequacies, many proponents of traditional IDL are beginning to look for ways to add environmental and social issues to their traditional economic concerns. However, many of them are doing so in a manner that treats environmental, social, political, cultural and economic matters as discrete areas of activity. They do not seek to integrate them into one holistic vision of development. The result, as can be seen in some of the contentious projects funded by the World Bank and in some attempts at expanding corporate social responsibility practices, is that environmental and social, including human rights, issues, are often seen as 'costs' of doing business rather than as an integral part of the development process.

The growing rejection of the traditional view of IDL does not necessarily mean there is a growing acceptance of the modern view. One reason for the reluctance of some to adopt the modern view is that while it has successfully articulated a new vision of development and the content of IDL, it has not yet been able to develop an operationally useable set of principles and legal doctrines.

The result of the clear inadequacy of the traditional view and the failure of modern IDL to develop operationally useful principles and doctrines is that the content of IDL remains a topic of vigorous debate

120 Grossman \& Bradlow (note 17 above) 12-14 (advances in information technology have enabled non-governmental actors to share information and spread activities across border and thus undermine states' authority to regulate and sanction their activities). 
incorporating a number of different issues. At the international level, the issues debated include the appropriate role in the development process of organisations like the Bretton Woods institutions and the WTO and of that of specific domestic and foreign stakeholders in major projects such as mining projects within one country. Another important issue in this debate is the appropriate role of the state and its relations with the other participants in the development process.

While the precise outcome of the debate is not easy to predict, it is clear that the future evolution of IDL will be in the direction of the modern view, although that might not be its final destination. This means that in the future, IDL is likely to include economic, environmental and human rights law. However, it is not yet discernible how exactly these different bodies of law will interact in the formation of the future doctrines of IDL. This suggests that IDL will, for years to come, provide many interesting and important challenges to lawyers specialising in the field. 